\title{
Tumour necrosis factor-beta polymorphism is unlikely to determine susceptibility to Type 1 (insulin-dependent) diabetes mellitus
}

\author{
D.Jenkins, M. A.Penny, C. H. Mijovic, K. H. Jacobs, J. Fletcher and A. H. Barnett \\ Department of Medicine, University of Birmingham and East Birmingham Hospital, Birmingham, UK
}

\begin{abstract}
Summary. Tumour necrosis factor gene polymorphism has been proposed as a determinant of Type 1 (insulin-dependent) diabetes mellitus. Tumour necrosis factor-beta gene polymorphisms were analysed in 40 North Indian Asian Type 1 diabetic patients and 63 control subjects. A 5.5 kilobase gene fragment was significantly increased among the patients $\left(82.5 \%\right.$ vs $\left.52 \%, p_{c}<0.01\right)$. A 10.5 kilobase fragment was significantly reduced among the patients (70\% vs $90.5 \%$, $p_{\mathrm{c}}<0.02$ ). The 5.5 kilobase fragment was associated with DR3, and was not significantly increased among DR3-positive patients compared with DR3-positive control subjects. The 5.5 kilobase $/ 5.5$ kilobase genotype was increased among
\end{abstract}

the diabetic subjects ( $30 \%$ vs $9.5 \%, p_{\mathrm{c}}<0.03$ ). The 10.5 kilobase/10.5 kilobase genotype was reduced among the diabetic subjects $\left(17.5 \%\right.$ vs $\left.47.5 \%, p_{c}<0.02\right)$. The 5.5 kilobase/10.5 kilobase genotype was not significantly associated with disease. These findings contrast with those in a white Caucasian population, suggesting that tumour necrosis factor-beta polymorphisms do not predispose to Type 1 diabetes directly, but are in linkage disequilibrium with disease susceptibility alleles at other MHC loci.

Key words: Diabetes mellitus, Indian Asian, MHC, tumour necrosis factor, linkage disequilibrium.
Inherited predisposition to Type 1 (insulin-dependent) diabetes mellitus is partly encoded by genes within the MHC [1,2]. Infrequent recombination (linkage disequilibrium) between $\mathrm{MHC}$ genes hinders precise mapping of disease susceptibility. Although DR3- and DR4-associated DQ alleles are associated with Type 1 diabetes in various populations, they occur on both predisposing and non-predisposing haplotypes [3]. Such alleles may not influence Type 1 diabetes directly, but may be in linkage disequilibrium with susceptibility alleles at other MHC loci. Alternatively, DQ-encoded disease predisposition may be altered by other susceptibility genes.

Tumour necrosis factors-alpha and -beta (TNF- $\alpha$ and TNF- $\beta$ ) are MHC-encoded [4] and may determine susceptibility to Type 1 diabetes $[5,6]$. Heterozygosity for a TNF- $\beta$ (detected by a TNF- $\alpha$ cDNA probe, see methods) restriction fragment length polymorphism (RFLP) was positively associated with the disease in a white Caucasian population [5]. The RFLP was caused by non-coding polymorphism [7], and its functional significance is unclear. Type 1 diabetes may be associated with TNF- $\beta$ RFLPs because of linkage disequilibrium between the RFLPs and disease-predisposing alleles at other loci.

Linkage disequilibrium between MHC alleles varies between populations [8]. MHC alleles which predispose to Type 1 diabetes should be associated with the disease in all populations, in spite of differences in linkage disequilibrium [3]. In North Indian Asians, Type 1 diabetes is associated with DR3, and more weakly associated with DR4 [9]. A DR-typed North Indian population was examined to determine whether associations between TNF- $\beta$ RFLPs and Type 1 diabetes were similar to those observed in white Caucasian subjects.

\section{Subjects and methods}

Forty North Indian Asian (Punjabi) subjects with Type 1 diabetes and 63 healthy, unrelated, racially-matched control subjects were studied. Diabetic subjects were ketosis-prone, diagnosed at less than 30 years of age and continuously dependent on insulin from diagnosis. All subjects were second or third generation residents in the UK and had been serologically DR-typed previously [9]. DNA $(7 \mu \mathrm{g})$ from each subject was digested with $10 \mathrm{U} N \mathrm{Nco}$ I (BRL) for $6 \mathrm{~h}$ at $37^{\circ} \mathrm{C}$, separated in $0.7 \%$ agarose and blotted onto nylon filters (Hybond-N, Amersham, Amersham, UK). Filters were hybridized with radiolabelled TNF- $\alpha$ cDNA under conditions described previously [9]. An Nco I restriction site occurs within the TNF $\alpha$ gene, and a variable $\mathrm{Nco}$ I site occurs in the first intron of the closely linked TNF- $\beta$ gene [7]. These sites allow the TNF- $\alpha$ cDNA probe to detect 10.5 kilobase $(\mathrm{kb})$ and $5.5 \mathrm{~kb}$ Nco I TNF- $\beta$ RFLPs. 
Table 1. TNF- $\beta$ RFLP frequencies in North Indian Type 1 (insulindependent) diabetic patients and control subjects

\begin{tabular}{lllll}
\hline $\begin{array}{l}\text { TNF- } \beta \\
\text { RFLP }\end{array}$ & $\begin{array}{l}\text { Patients } \\
(n=40)\end{array}$ & $\begin{array}{l}\text { Control subjects } \\
(n=63)\end{array}$ & RR & $p_{c}$ \\
\hline $5.5 \mathrm{~kb}$ & $33(82.5)$ & $33(52)$ & $4.1(1.6-10.2)$ & $<0.01$ \\
$10.5 \mathrm{~kb}$ & $28(70)$ & $57(90.5)$ & $0.26(0.09-0.72)$ & $<0.02$ \\
\hline
\end{tabular}

Figures in parenthesis after the restriction fragment length polymorphism (RFLP) frequencies are percentages. RR is the relative risk with the $95 \%$ confidence limits shown in parenthesis. $p_{c}$ is the $p$ value corrected for the number of tests performed. $\mathrm{kb}=$ kilobase

Table 2. TNF- $\beta$ RFLP frequencies in North Indian DR3-positive Type 1 (insulin-dependent) diabetic patients and control subjects

\begin{tabular}{rlll}
\hline TNF- $\beta$ & $\begin{array}{l}\text { Patients } \\
\text { RFLP }\end{array}$ & $\begin{array}{l}\text { Control subjects } \\
(n=31)\end{array}$ & $p$ \\
\hline $5.5 \mathrm{~kb}$ & $29(93.5)$ & $13(76.4)$ & NS \\
$10.5 \mathrm{~kb}$ & $19(61.2)$ & $12(70.1)$ & NS \\
\hline
\end{tabular}

Figures in parenthesis are percentages. RFLP $=$ restriction fragment length polymorphism; $\mathrm{kb}=$ kilobase

\section{Statistical analysis}

Associations between Type 1 diabetes and TNF- $\beta$ RFLPs were analysed by the $X^{2}$ test. Correlation coefficients $(r)$ for associations between DR types and TNF- $\beta$ RFLPs were calculated from: $r=\left(X^{2} / n\right)^{1 / 2}$, where $n=$ the number of subjects. Associations between TNF- $\beta$ RFLPs and Type 1 diabetes in DR3-positive subjects were analysed by Fisher's exact test.

\section{Results}

A $5.5 \mathrm{~kb}$ RFLP and a $10.5 \mathrm{~kb}$ RFLP were detected. Their frequencies are shown in Table 1 . The $5.5 \mathrm{~kb}$ RFLP was significantly increased among the diabetic subjects, $\mathrm{RR}=4.1(95 \%$ confidence limits $=1.62-10.2), p_{\mathrm{c}}<0.01$. The $10.5 \mathrm{~kb}$ RFLP was significantly reduced among the diabetic subjects, $\mathrm{RR}=0.26(0.09-0.72), p_{\mathrm{c}}<0.02$.

The $5.5 \mathrm{~kb}$ RFLP was significantly associated with DR3 in both the control group, $r=0.3, p<0.025$, and in the diabetic group, $r=0.4, p<0.025$. The $10.5 \mathrm{~kb}$ RFLP was significantly associated with $\mathrm{DR} 4$ in the diabetic group, $r=0.4, p<0.025$, but was not significantly associated with any DR type in the control group.

There was no significant difference in frequency of either the $5.5 \mathrm{~kb}$ RFLP or the $10.5 \mathrm{~kb}$ RFLP among DR3positive diabetic subjects compared with DR3-positive control subjects (Table 2). TNF- $\beta$ genotypes were grouped into one of the $5.5 / 5.5,5.5 / 10.5$ or $10.5 / 10.5$ classes, according to the RFLPs. The genotypes are shown in Table 3. The 5.5/5.5 class was significantly increased among the diabetic subjects, $p_{c}<0.03$. The $10.5 / 10.5$ class was significantly reduced among the diabetic subjects, $p_{c}<0.02$. The $5.5 / 10.5$ class did not occur significantly differently in the diabetic and control subjects.

For comparison, DR genotype frequencies are shown in Table 4. DR3/3 homozygotes were significantly increased in the diabetic group, $p_{\mathrm{c}}<10^{-5}$, as were DR3/4 heterozygotes, $p_{\mathrm{c}}<0.05$. DRX/X subjects (where " $\mathrm{X}$ " is any non-DR3, non-DR4 haplotype) were significantly reduced in the diabetic group, $p_{\mathrm{c}}<10^{-5}$.

\section{Discussion}

TNF- $\alpha$ and TNF- $\beta$ are cytokines which are implicated in inflammatory responses [10]. In vitro studies have shown that TNF- $\alpha$ increases pancreatic Beta-cell damage [11], and TNF- $\alpha$ gene polymorphisms have been suggested as determinants of predisposition to Type 1 diabetes $[5,6$, 12].

This study demonstrated TNF- $\beta$ RFLPs in North Indian subjects identical to those observed in white Caucasian subjects [5, 7]. The $5.5 \mathrm{~kb}$ RFLP was positively associated with Type 1 diabetes, and the $10.5 \mathrm{~kb}$ RFLP was negatively associated. Although the $5.5 \mathrm{~kb}$ RFLP was also increased in white Caucasian Type 1 diabetic subjects, the $10.5 \mathrm{~kb}$ RFLP was not reduced among the diabetic subjects in that population [5].

In white Caucasians, the $5.5 \mathrm{~kb}$ TNF- $\beta$ RFLP occurs on most B8-DR3 haplotypes, the $10.5 \mathrm{~kb}$ RFLP on most Bw62-DR4 haplotypes [5, 7]. This suggests that the $5.5 \mathrm{~kb}$ RFLP is associated with Type 1 diabetes because of linkage disequilibrium with DR3. Although neither serological $\beta$-typing, nor typing of family members were performed in this North Indian study, DR3 was associated with the $5.5 \mathrm{~kb}$ RFLP in both the diabetic and control groups, indicating that the $5.5 \mathrm{~kb}$ RFLP occurs on most North Indian DR3 haplotypes. The $5.5 \mathrm{~kb}$ RFLP did not confer additional disease susceptibility to that conferred by DR3.

Heterozygosity for the TNF- $\beta$ RFLP was not significantly associated with Type 1 diabetes, in contrast with the

Table 3. TNF- $\beta$ genotype frequencies in North Indian Type 1 (insulin-dependent) diabetic patients and control subjects

\begin{tabular}{llll}
$\begin{array}{l}\text { TNF- } \beta \\
\text { genotype }\end{array}$ & $\begin{array}{l}\text { Patients } \\
(n=40)\end{array}$ & $\begin{array}{l}\text { Control subjects } \\
(n=63)\end{array}$ & $p_{\mathrm{c}}$ \\
\hline $5.5 / 5.5$ & $12(30)$ & $6(9.5)$ & $<0.03$ \\
$5.5 / 10.5$ & $21(52.5)$ & $27(43)$ & $\mathrm{NS}$ \\
$10.5 / 10.5$ & $7(17.5)$ & $30(47.5)$ & $<0.02$ \\
\hline
\end{tabular}

Figures in parenthesis following genotype frequencies are percentages. $p_{c}$ is the $p$ value corrected for the number of TNF- $\beta$ genotypes considered

Table 4. DR genotype frequencies in North Indian Type 1 (insulindependent) diabetic patients and control subjects

\begin{tabular}{llcl}
\hline $\begin{array}{l}\text { DR } \\
\text { genotype }\end{array}$ & $\begin{array}{l}\text { Patients } \\
(n=40)\end{array}$ & $\begin{array}{l}\text { Control subjects } \\
(n=63)\end{array}$ & $p_{\mathrm{c}}$ \\
\hline $3 / 3$ & $15(37.5)$ & $1(1.5)$ & $<10^{-5}$ \\
$3 / 4$ & $8(20)$ & $2(3)$ & $<0.05$ \\
$3 / \mathrm{X}$ & $9(22.5)$ & $14(22)$ & $\mathrm{NS}$ \\
$4 / 4$ & $0(0)$ & $0(0)$ & $\mathrm{NS}$ \\
$4 / \mathrm{X}$ & $3(7.5)$ & $4(6.5)$ & $\mathrm{NS}$ \\
$\mathrm{X} / \mathrm{X}$ & $5(12.5)$ & $42(66.5)$ & $<10^{-5}$ \\
\hline
\end{tabular}

"X" refers to any non-DR3, non-DR4 haplotype.

Figures in parenthesis following genotype frequencies are percentages. $p_{c}$ is the $p$-value corrected for the number of DR genotypes considered 
findings in white Caucasians [5]. It was suggested that TNF- $\beta$ RFLP heterozygosity might explain the high risk of Type 1 diabetes associated with DR3/4 heterozygosity [5]. The North Indian data suggest otherwise. TNF- $\beta$ RFLP heterozygosity was not significantly associated with Type 1 diabetes in this race, in contrast with DR3/4 heterozygosity. In addition, the positive association between $5.5 \mathrm{~kb}$ homozygosity and Type 1 diabetes in North Indians did not occur in white Caucasians. These differences suggest that TNF- $\beta$ genotypes are associated with Type 1 diabetes because of linkage disequilibrium between TNF$\beta$ RFLPs and susceptibility alleles at other loci on DR3 and DR4 haplotypes.

These data do not support the TNF- $\beta$ gene as a determinant of Type 1 diabetes. This is consistent with data from Japanese subjects [13] and is not surprising since the TNF- $\beta$ RFLPs are determined by non-coding polymorphism of doubtful functional significance. Although other variations within TNF- $\beta$ (or the closely associated TNF- $\alpha$ ) coding and/or regulatory sequences may be in linkage disequilibrium with the RFLPs, they have not been detected by several restriction enzymes [5, 7]. Unless either the coding or regulatory regions of the TNF- $\alpha$ and TNF- $\beta$ genes contain functionally important polymorphism, these loci are unlikely to contribute to inherited susceptibility to Type 1 diabetes.

Acknowledgements. We thank Dr. M. Bodmer of Celltech Ltd. for the gift of the TNF- $\alpha$ cDNA probe. DJ, MAP, CM, and KHJ are supported by Eli Lilly (UK), the Medical Research Council, the Wellcome Trust and the British Diabetic Association respectively. We gratefully acknowledge additional financial support from these bodies.

\section{References}

1. Rotter JI, Landaw EM (1984) Measuring the genetic contribution of a single locus to a multilocus disease. Clin Genet 26: 529 542

2. Thomson G, Robinson WP, Kuhner MK et al. (1988) Genetic heterogeneity, modes of inheritance, and risk estimates for a joint study of Caucasians with insulin-dependent diabetes mellitus. Am J Hum Genet 43: 799-816
3. Jenkins D, Mijovic C, Fletcher J, Jacobs KH, Bradwell AR, Barnett AH (1990) Identification of susceptibility loci for Type 1 (insulin-dependent) diabetes by trans-racial gene mapping. Diabetologia 33: 387-395

4. Spies T, Morton CC, Neodospasov SA, Fiers W, Pious D, Strominger JL (1986) Genes for the tumour necrosis factors $\alpha$ and $\beta$ are linked to the human major histocompatibility complex. Proc Natl Acad Sci USA 83: 8699-8702

5. Badenhoop K, Schwarz G, Trowsdale J et al. (1989) TNF- $\alpha$ gene polymorphisms in Type 1 (insulin-dependent) diabetes mellitus. Diabetologia 32: 445-448

6. Molvig J, Pociot F, Baek L et al. (1990) Monocyte function in IDDM patients and healthy individuals. Scand $\mathbf{J}$ Immunol 32 : 297-311

7. Webb GC, Chaplin DD (1990) Genetic variability at the human tumour necrosis factor loci. J Immunol 145: 1278-1285

8. Baur MP, Neugebauer M, Albert ED (1984) Reference tables of two-locus haplotype frequencies for all MHC marker loci. In: Albert ED, Baur MP, Mayr WR (eds) Histocompatibility testing. Springer, Berlin Heidelberg New York

9. Odugbesan O, Fletcher J, Mijovic C, Mackay E, Bradwell AR, Barnett AH (1987) The HLA-D associations of Type 1 (insulindependent) diabetes in Punjabi Asians in the United Kingdom. Diabetologia 30: 618-621

10. Old LJ (1987) Tumour necrosis factor: polypeptide mediator network. Nature 326: 330-331

11. Mandrup-Poulsen T, Bendtzen K, Dinarello CK, Nerup J (1987) Human tumour necrosis factor potentiates human interleukin-1 mediated rat pancreatic B-cell cytotoxicity. J Immunol 139: 4077-4082

12. Molvig J, Baek L, Christensen P et al. (1988) Endotoxin-stimulated human monocyte secretion of interleukin-1, tumour necrosis factor alpha and prostaglandin $\mathrm{E}_{2}$ show stable interindividual differences. Scand J Immunol 27: 705-716

13. Yamagata K, Hanafusa T, Nakajima $H$ et al. (1991) HLADQA $1 * 1$ contributes to resistance and $\mathrm{A} 1 * 3$ confers susceptibility to Type 1 (insulin-dependent) diabetes mellitus in Japanese subjects. Diabetologia 34: 133-136

Received: 21 January 1991

and in revised form: 25 March 1991

Dr. D. Jenkins

Department of Medicine

Queen Elizabeth Hospital

Birmingham B152TH

UK 